\title{
The Impact of Movement Control Order (MCO) during Pandemic COVID-19 on Local Air Quality in an Urban Area of Klang Valley, Malaysia
}

\author{
Mohd Shahrul Mohd Nadziri", Maggie Chel Gee Ooi ${ }^{2}$, Kemal Maulana Alhasa ${ }^{3}$, \\ Mohd Aftar Abu Bakar ${ }^{5}$, Anis Asma Ahmad Mohtar ${ }^{1}$, Mohd Fadzil Firdzaus Mohd Nor6, \\ Mohd Talib Latif ${ }^{1}$, Haris Hafizal Abd Hamid ${ }^{1}$, Sawal Hamid Md Ali ${ }^{7}$, Noratiqah Mohd Ariff ${ }^{5}$, \\ Johary Anuar $^{9}$, Fatimah Ahamad ${ }^{4}$, Azliyana Azhari' ${ }^{1}$, Norfazrin Mohd Hanif ${ }^{1}$, \\ Mohammed Ahmed Subhi ${ }^{7}$, Murnira Othman ${ }^{8}$, Mohd Zaim Mohd Nor?
}

${ }^{1}$ Department of Earth Sciences and Environment, Faculty of Science and Technology, Universiti Kebangsaan Malaysia, Bangi 43600, Selangor, Malaysia

${ }^{2}$ Institute of Climate Change, Earth Observatory Center, Universiti Kebangsaan Malaysia, Bangi 43600, Selangor, Malaysia

${ }^{3}$ Institute of Climate Change, Space Science Centre (ANGKASA), Universiti Kebangsaan Malaysia, Bangi 43600, Selangor, Malaysia

${ }^{4}$ Institute of Climate Change, Centre for Tropical System and Climate Change (IKLIM), Universiti Kebangsaan Malaysia, Bangi 43600, Selangor, Malaysia

${ }^{5}$ Department of Mathematical Sciences, Faculty of Science and Technology, Universiti Kebangsaan Malaysia, 43600, Bangi, Selangor, Malaysia

${ }^{6}$ Institute of Ocean and Earth Sciences, IAS Building, University of Malaya, 50603, Kuala Lumpur, Malaysia

${ }^{7}$ Department of Electrical, Electronic and Systems Engineering, Faculty of Engineering and Built Environment, Universiti Kebangsaan Malaysia, Bangi 43600, Selangor, Malaysia

${ }^{8}$ Institute for Environmental and Development (LESTARI), Universiti Kebangsaan Malaysia, Bangi 43600, Selangor, Malaysia

${ }^{9}$ Petaling Jaya City Council, Jalan Yong Shook Lin, 46675 Petaling Jaya, Selangor Darul Ehsan, Malaysia

\begin{abstract}
The world is currently going through the COVID-19 pandemic which has caused hundreds of thousands of deaths in just a few months. Considering the need for lockdown measures, most countries, including Malaysia, have implemented 'Movement Control Orders' (MCOs) as a prevention step to reduce the deadly spread of this disease. Local and worldwide media have reported the immediate improvement of air quality due to this event. Nevertheless, data on the effects of MCOs on air quality at local scales are still sparse. Here, we investigate changes in air quality during the MCO at an urban area using the air sensor network AiRBOXSense which measures monoxide (CO) and particulate matter $\left(\mathrm{PM}_{2.5}\right.$ and $\left.\mathrm{PM}_{10}\right)$. In this study, air pollutant data during normal days were compared with MCO days using a reference analyser and AiRBOXSense. The results showed that the levels of the measured pollutants dropped by 20 to $60 \%$ during the MCO days at most locations. However, CO in Kota Damansara (KD) dropped to $48.7 \%$, but $\mathrm{PM}_{2.5}$ and $\mathrm{PM}_{10}$ increased up to $60 \%$ and $9.7 \%$ respectively during MCO days. Local burning activities in the residential area of KD are believed to be the main cause of the increased PM levels. This study has proven that air pollutant levels have significantly fallen due to the MCO. This air quality level information showed that the reduction of air pollutants can be achieved if traffic and industry emissions are strictly controlled.
\end{abstract}

Keyword: Movement Control Order; Carbon monoxide; Particulate matters.

\footnotetext{
${ }^{\dagger}$ Now at Petaling District and Land Office complex, 40150 Shah Alam, Selangor Darul Ehsan, Malaysia

* Corresponding author.

E-mail address: shahrulnadzir@ukm.edu.my
}

\section{INTRODUCTION}

The World Health Organization (WHO) declared the COVID-19 outbreak as a pandemic on $11^{\text {th }}$ March 2020 (WHO, 2016, 2020). In many countries, including Malaysia, a pandemic action plan has been announced by authorities. 
One of the action plans is known as a Movement Control Order in Malaysia (MCO) to stop the spread of COVID-19 while transmission and mitigation can be further understood (Hadei et al., 2020; Hsiao et al., 2020). Owing to the restriction of movement, only limited essential services such as healthcare, logistics, the food supply chain and banking are allowed to operate. Therefore, there are fewer vehicles on the roads, many cancelled flights and restricted construction and industrial activities which has led to plummeting levels of air pollutants. Hence, there has been an ancillary health benefit of reducing air pollution due to the MCO.

Air quality is an important factor that any government needs to manage and control. Increased levels of air pollutants will affect human health, causing respiratory and skin problems. According to data supplied by the World Health Organization, air pollution and poor air quality result in 5.5 million unnecessary deaths annually (WHO, 2016). The main sources of air pollution in urban areas are combustion from vehicles, power generation plants, landfill sites, wastewater treatment plants and unsustainable farming. The emissions of air pollutants such as volatile organic compounds (VOCs), carbon monoxide $(\mathrm{CO})$, nitrogen dioxide $\left(\mathrm{NO}_{2}\right)$, ozone $\left(\mathrm{O}_{3}\right)$, sulphur dioxide $\left(\mathrm{SO}_{2}\right)$ and particulate matter $(\mathrm{PM})$ need to be monitored at high resolution in urban areas since these compounds will deteriorate human health if present at high concentrations (Latif et al., 2012; Banan et al., 2013; Nadzir et al., 2018).

Recently, satellite measurements of air pollutants during the COVID-19 pandemic from the European Space Agency have shown that during late January and early February 2020, air pollution decreased markedly. The maps on changes in $\mathrm{NO}_{2}$ produced by the Royal Netherlands Meteorological Institute (KNMI) using a Tropomi instrument on the Copernicus Sentinel-5P satellite (https://theconversation.com) showed lockdown in Europe resulted in reductions in $\mathrm{NO}_{2}$ emissions. In India, air pollution levels have dropped by $71 \%$ in just one week and $\mathrm{PM}_{2.5}$ dropped from 91 to $27 \mu \mathrm{g} \mathrm{m}^{-3}$ from the $20^{\text {th }}$ to the $27^{\text {th }}$ March 2020 (https://www.ecowat ch.com/india-air-pollution-coronavirus-2645617908.html). A model study suggested that air quality in India has improved slightly if similar emission reduction during $\mathrm{MCO}$ occurs under unfavourable meteorological conditions in India. In addition, Xu et al. (2020) reported that three cities in central China, the Hubei Province, Wuhan, Jingmen, and Enshi, recorded total reductions of air pollutants during the pandemic of $30.1 \%, 40.5 \%, 33.4 \%, 27.9 \%$, and $61.4 \%$ for $\mathrm{PM}_{2.5}, \mathrm{PM}_{10}, \mathrm{SO}_{2}, \mathrm{CO}$, and $\mathrm{NO}_{2}$, respectively.

In Malaysia, $\mathrm{PM}_{2.5}$ reductions of $58.4 \%$ were first observed over the Peninsular Malaysia region during the $\mathrm{MCO}$ period (Abdullah et al., 2020). However, this study focused on $\mathrm{PM}_{2.5}$ and does not cover other crucial pollutants such as $\mathrm{CO}$ and $\mathrm{PM}_{10}$. Although the 65 reference monitoring stations provide a good overview of air quality in the country, they are generally located away from emission sources and are unable to provide observations at high spatial resolutions. Therefore, low-cost air quality sensors for air quality measurements are deployed by local authorities and researchers globally to fill in the research gap (Alavi-Shoshtari et al., 2013; Austin et al., 2015; Alhasa et al., 2018). One potential solution for air pollution monitoring in urban areas is the use of 'Low-cost Air Quality Sensors' or LAQS. These provide good air pollution data at high spatial-temporal resolutions

This study aims to investigate the air quality pollutants carbon monoxide $(\mathrm{CO})$ and particulate matter $\left(\mathrm{PM}_{10}\right.$ and $\mathrm{PM}_{2.5}$ ) at a local scale in an urban area both during normal days and the MCO period using LAQS, namely AiRBOXSense. Secondary data from the Department of Environment Malaysia (DOE) and the AiRBOXSense data will be used for validations. The meteorological and wind trajectory influences will be evaluated using ERA5 data. Finally, this study will provide an insight into a potential future with less air pollution and will assist us in formulating achievable air quality management and control procedures.

\section{METHODS}

\section{Field Measurement and Data Analyses}

Details of the AiRBOXSense system have been published in previous work by Alhasa et al. (2018), where it was known as 'Dirac Sense'. There are slight modifications of the system now named AiRBOXSense. The specific requirements for our sensing system were reliability and durability while being low cost, portable and easy to install by the user. AiRBOXSense collects, analyses and shares air quality data using the wireless communication network. Using the Internet of Things (IoT) scenario allows data to be sent to remote cloud storage such as Thingspeak periodically as well as the near-real-time visualization of numerical and graphical values over time. In this study, the $\mathrm{CO}$ electrochemical sensor (EC) and the optical particle sensor (OPC-N2) for PM measurements were manufactured by Alphasense (Alphasense Ltd., Great Notley, Braintree, UK). Details of the AiRBOXSense calibrations, configurations and operations were described in our previous work (Alhasa et al., 2018). In this study, a GRIMM portable aerosol spectrometer (PAS-1.108) was used as a reference instrument for validation purposes for $\mathrm{PM}_{2.5}$ and $\mathrm{PM}_{10}$ with correlation coefficient $\mathrm{r}^{2}$ values of 0.71 and 0.83 for $\mathrm{PM}_{2.5}$ and $\mathrm{PM}_{10}$, respectively.

In addition, we used secondary data obtained from the Malaysia Department of Environment's (DOE) continuous air quality monitoring system (CAQMS) to support the sensor data. However, due to the introduction of $\mathrm{PM}_{2.5}$ measurement components in 2017, we are limited to using historical data from 2017 to 2018 at the nearest CAQMS stations. The DOE data will be compared with the sensor data during a normal day $\left(\sim 20^{\text {th }}\right.$ November $2019-17^{\text {th }}$ March 2020) and during the MCO (18 ${ }^{\text {th }}$ March $2020-12^{\text {th }}$ April 2020) from the sensor. The wind data used in this study was the ERA5 data from the European Centre for MediumRange Weather Forecasts (ECMWF). The data used were $10 \mathrm{~m}$ wind components with $31 \mathrm{~km}$ horizontal resolution and an hourly temporal resolution. The ERA5 data are provided freely by the Copernicus Climate Change Service of the ECMWF on their website (C3S, 2017). While there are five different locations of sensor stations in this study, they are all within the same $31 \mathrm{~km} \times 31 \mathrm{~km}$ grid with similar data values. 


\section{Sensors and CAQMS Stations}

In this study, two types of data will be obtained, the first by the air quality sensors and the second by reference instruments for comparison and validation. Five AiRBOXSense sensors were deployed at different locations in Petaling Jaya: Bukit Gasing (BG), Petaling Jaya City (PJ), Kelana Jaya (KJ), Uptown PJ (UP) and Kota Damansara (KD), respectively (see Fig. 1). Secondary data from seven CAQMS stations close to the AiRBOXSense sensor locations were used in this study to investigate the background levels of $\mathrm{CO}, \mathrm{PM}_{2.5}$ and $\mathrm{PM}_{10}$ during normal days from the previous year, November 2017 to April 2018. All stations are located less than $20 \mathrm{~km}$ from PJ.

\section{Backward Trajectories Analysis}

To investigate the possible sources that could contribute towards high concentration events of the measured pollutants during the MCO period, the backward trajectory analysis was conducted to track the origin of air masses arriving at the measurement sites. The analysis was performed using the Hybrid Single Particle Lagrangian Integrated Trajectory model (HYSPLIT) developed by the National Oceanic and Atmospheric Administration (NOAA)'s Air Resource Laboratory (ARL) (Draxler and Rolph, 2003; Rolph, 2003) which is available online (https://ready.arl.noaa.gov/hypub- bin/trajtype.pl). The model was run in the backward mode for 72 hours from 0-100 $\mathrm{m}$ above the surface of the measurement sites where the high pollution event was observed.

\section{MODIS Active Fire Product}

Active fire/hotspot data from NASA's Moderate Resolution Imaging Spectroradiometer (MODIS) (Justice et al., 2002) were retrieved during the $\mathrm{MCO}$ period to examine possible sources from active fires near the measurement sites. The collection 6 Terra and Aqua MODIS active fire data which produced moderate resolution $(\sim 1 \mathrm{~km})$ was downloaded from the Fire Information for Resource Management System (FIRMS) of NASA's Land, Atmosphere Near real-time Capability for Earth Observing System (LANCE).

\section{RESULTS AND DISCUSSION}

\section{Ground Station Data}

The overall average concentration values during the normal period (28 ${ }^{\text {th }}$ November 2019 to $17^{\text {th }}$ April 2020) from the CAQMS stations for $\mathrm{CO}, \mathrm{PM}_{2.5}$ and $\mathrm{PM}_{10}$ were $1.2 \pm$ $0.3 \mathrm{ppm}, 22.1 \pm 4.4 \mu \mathrm{g} \mathrm{m}^{-3}$ and $45.4 \pm 10.8 \mu \mathrm{g} \mathrm{m}^{-3}$, respectively (See Table 1). The maximum concentrations for $\mathrm{CO}, \mathrm{PM}_{2.5}$ and $\mathrm{PM}_{10}$ were in the ranges 1.92 to $3.51 \mathrm{ppm}$, 43.1 to $155 \mu \mathrm{g} \mathrm{m}^{-3}, 57.9$ to $180 \mu \mathrm{g} \mathrm{m}^{-3}$, respectively.

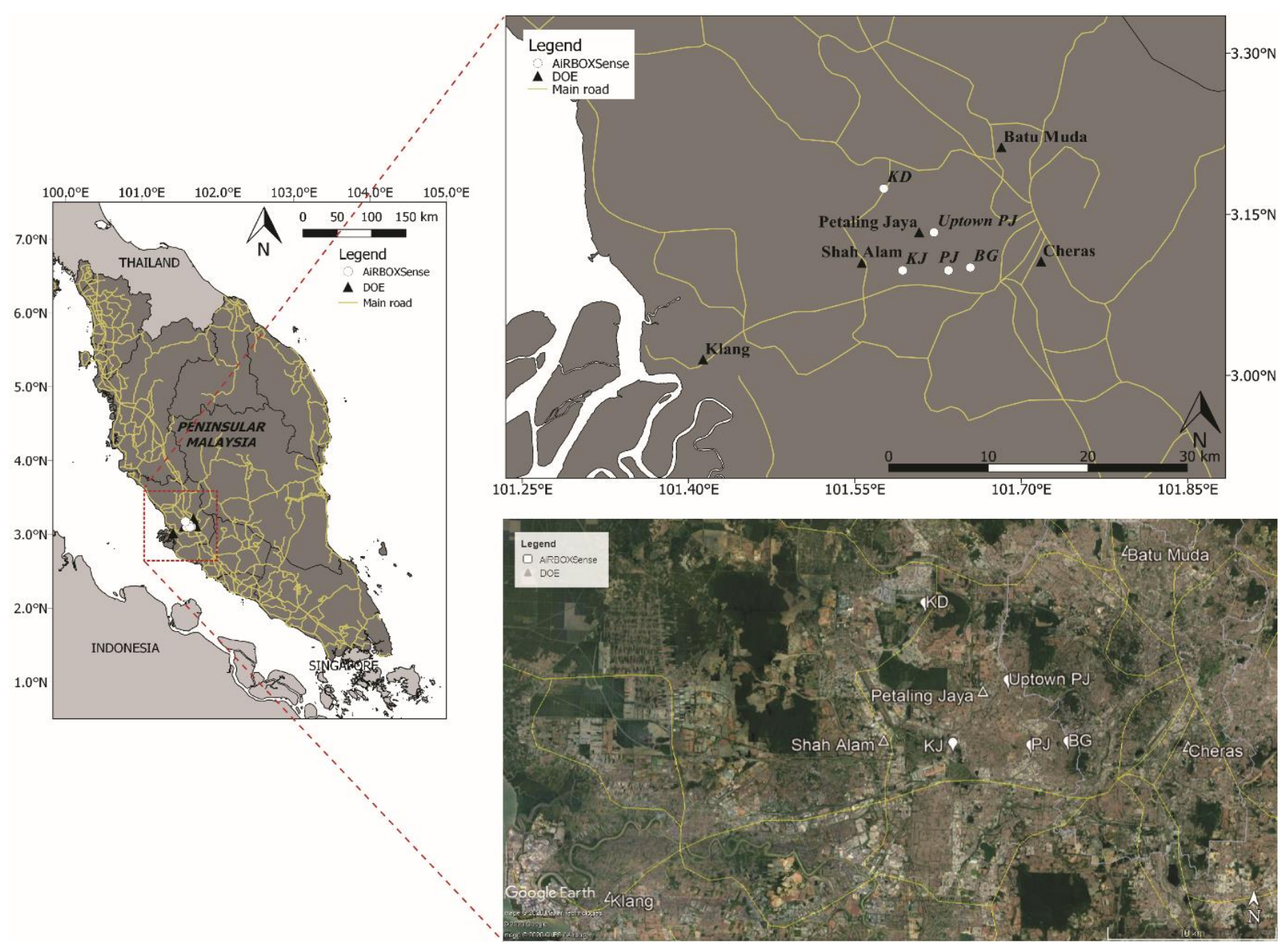

Fig. 1. CAQMS stations and sensor locations in the Petaling Jaya district and Klang Valley region. 
Table 1. Daily average concentrations of $\mathrm{CO}, \mathrm{PM}_{10}$ and $\mathrm{PM}_{2.5}$ over Cheras, Shah Alam, Batu Muda, Klang and Petaling Jaya recorded by CAQMS stations from $1^{\text {st }}$ November 2017 to $14^{\text {th }}$ April 2018.

\begin{tabular}{lllllll}
\hline & & \multicolumn{5}{c}{ CAQMS } \\
\hline Pollutants & & Cheras & Shah Alam & Batu Muda & Klang & Petaling Jaya \\
\hline $\mathrm{CO}(\mathrm{ppm})$ & Min & 0.42 & 0.28 & 0.33 & 0.49 & 0.58 \\
& Max & 2.54 & 1.94 & 1.92 & 3.51 & 3.12 \\
& average & 0.99 & 0.86 & 0.91 & 1.05 & 1.36 \\
$\mathrm{PM}_{10}\left(\mu \mathrm{g} \mathrm{m}^{-3}\right)$ & Min & 15.3 & 10.0 & 8.20 & 20.7 & 16.2 \\
& Max & 127 & 131 & 141 & 180 & 57.9 \\
& Average & 36.8 & 41.7 & 34.8 & 43.5 & 34.7 \\
$\mathrm{PM}_{2.5}\left(\mu \mathrm{g} \mathrm{m}^{-3}\right)$ & Min & 7.83 & 7.40 & 5.15 & 10.5 & 9.09 \\
& Max & 46.6 & 51.3 & 47.9 & 155 & 43.1 \\
& average & 21.4 & 24.1 & 17.6 & 26.5 & 24.8 \\
\end{tabular}

\section{Sensor Data}

Normal Day

During the normal days, the daily average concentrations for $\mathrm{CO}, \mathrm{PM}_{2.5}$ and $\mathrm{PM}_{10}$ in the $\mathrm{PJ}$ area measured by AiRBOXSense were $0.54 \pm 0.14 \mathrm{ppm}, 19.1 \pm 9.75 \mu \mathrm{g} \mathrm{m}^{-3}$ and $35.5 \pm 17.6 \mu \mathrm{g} \mathrm{m}^{-3}$, respectively. The highest concentrations were observed during peak hours between 0700 to 0900 and 1700 to 2000. This is due to the heavy traffic emissions at those times. These average daily concentration values were similar to the observations from the CAQMS station except $\mathrm{CO}$ where the AiRBOXSense data were slightly lower than the CAQMS data (see Table 2, Figs. 2(a)-2(e) and Fig. 3(a)3(c)). During normal days, the BG site recorded the highest amount of $\mathrm{PM}_{2.5}\left(1540 \mu \mathrm{g} \mathrm{m}^{-3}\right)$ and $\mathrm{PM}_{10}\left(7110 \mu \mathrm{g} \mathrm{m}^{-3}\right)$ despite being a recreation park where people came for fresh and clean air. KD and KJ stations that are along the main road and highway each recorded high amount of $\mathrm{PM}_{10}$ $\left(3460 \mu \mathrm{g} \mathrm{m}^{-3}\right.$ and $2260 \mu \mathrm{g} \mathrm{m}^{-3}$ ) capturing the mobile emission from the daily commute. The daily concentrations of $\mathrm{CO}$, $\mathrm{PM}_{2.5}$ and $\mathrm{PM}_{10}$ are shown in Fig. 2(a)-2(e) and Fig. 3(a)3(c).

\section{MCO day}

The period of $\mathrm{MCO}$ has three phases which were $18^{\text {th }}$ March-31 $1^{\text {st }}$ March 2020 ( $1^{\text {st }}$ phase), $1^{\text {st }}$ April-14 ${ }^{\text {th }}$ April 2020 ( $2^{\text {nd }}$ phase) and $15^{\text {th }}$ April-28 $8^{\text {th }}$ April 2020 ( $3^{\text {rd }}$ phase $)$. However, the sensor data shown in this study is runs to $8^{\text {th }}$ April 2020. The air pollutant levels recorded dropped at most of the sensor locations. The levels dropped $\sim 20 \%$ to $60 \%$ (see Table 3). The sensors were deployed close to residential areas such as flats and apartments. Table 2 summarizes the daily average concentrations during MCO at the five sensor locations in PJ. The $\mathrm{KD}$ site recorded increases of both $\mathrm{PM}_{2.5}$ and $\mathrm{PM}_{10}$ - these were increased by $60 \%$ and $9.7 \%$, respectively. The $\mathrm{KD}$ area is mainly surrounded by residential areas and small industries. To support this finding, we ran the back trajectories over the KD site (see Fig. 4). The period of the back trajectories was chosen to coincide with the MCO period (18-22 Mar 2020). Fig. 4 shows that the hotspot of burning activities in Peninsular Malaysia is some distance from the KD site and large-scale burning (detectable from satellite data) is not the major source of emission. The predominant origins of the back trajectories were from the north-east region.

Table 2. Daily average concentrations of $\mathrm{CO}, \mathrm{PM}_{10}$ and $\mathrm{PM}_{2.5}$ measured by AiRBOXSense at Bukit Gasing (BG), Kelana Jaya (KJ), Kota Damansara (KD), Petaling Jaya (PJ) and Uptown.

\begin{tabular}{|c|c|c|c|c|c|c|c|}
\hline \multirow{2}{*}{ Locations } & & \multicolumn{3}{|c|}{ Normal day } & \multicolumn{3}{|c|}{$\mathrm{MCO}$} \\
\hline & & $\mathrm{CO}(\mathrm{ppm})$ & $\mathrm{PM}_{2.5}\left(\mu \mathrm{g} \mathrm{m}^{-3}\right)$ & $\mathrm{PM}_{10}\left(\mu \mathrm{g} \mathrm{m}^{-3}\right)$ & $\mathrm{CO}(\mathrm{ppm})$ & $\mathrm{PM}_{2.5}\left(\mu \mathrm{g} \mathrm{m}^{-3}\right)$ & $\mathrm{PM}_{10}\left(\mu \mathrm{g} \mathrm{m}^{-3}\right)$ \\
\hline \multirow[t]{3}{*}{ BG } & Min & 0.01 & 0.100 & 0.100 & 0.0100 & 0.100 & 0.100 \\
\hline & Max & 8.88 & 1540 & 7110 & 1.94 & 477 & 2540 \\
\hline & Average & 0.400 & 28.8 & 54.1 & 0.240 & 11.8 & 26.0 \\
\hline \multirow[t]{3}{*}{$\mathrm{KJ}$} & Min & 0.0100 & 0.250 & 0.25 & 0.0100 & 0.34 & 0.34 \\
\hline & $\operatorname{Max}$ & 12.8 & 193 & 2260 & 2.30 & 155 & 936 \\
\hline & Average & 0.560 & 9.32 & 19.0 & 0.310 & 6.32 & 12.4 \\
\hline \multirow[t]{3}{*}{$\mathrm{KD}$} & Min & 0.0100 & 0.250 & 0.250 & 0.0200 & 0.54 & 0.54 \\
\hline & Max & 7.78 & 414 & 3460 & 5.11 & 213 & 3410 \\
\hline & Average & 0.550 & 21.4 & 32.9 & 0.300 & 36.4 & 38.4 \\
\hline \multirow[t]{3}{*}{ PJ City } & Min & 0.0100 & 0.140 & 0.140 & 0.0100 & 0.240 & 0.240 \\
\hline & $\operatorname{Max}$ & 8.02 & 101 & 849 & 0.850 & 38.7 & 266 \\
\hline & Average & 0.540 & 10.4 & 21.7 & 0.300 & 6.26 & 12.6 \\
\hline \multirow[t]{3}{*}{ UP } & Min & 3.46 & 0.380 & 0.380 & 0.0100 & 0.360 & 0.360 \\
\hline & Max & 8.59 & 300 & 1160 & 6.24 & 104 & 2010 \\
\hline & Average & 0.680 & 11.1 & 22.2 & 0.360 & 8.78 & 15.8 \\
\hline
\end{tabular}


(a)
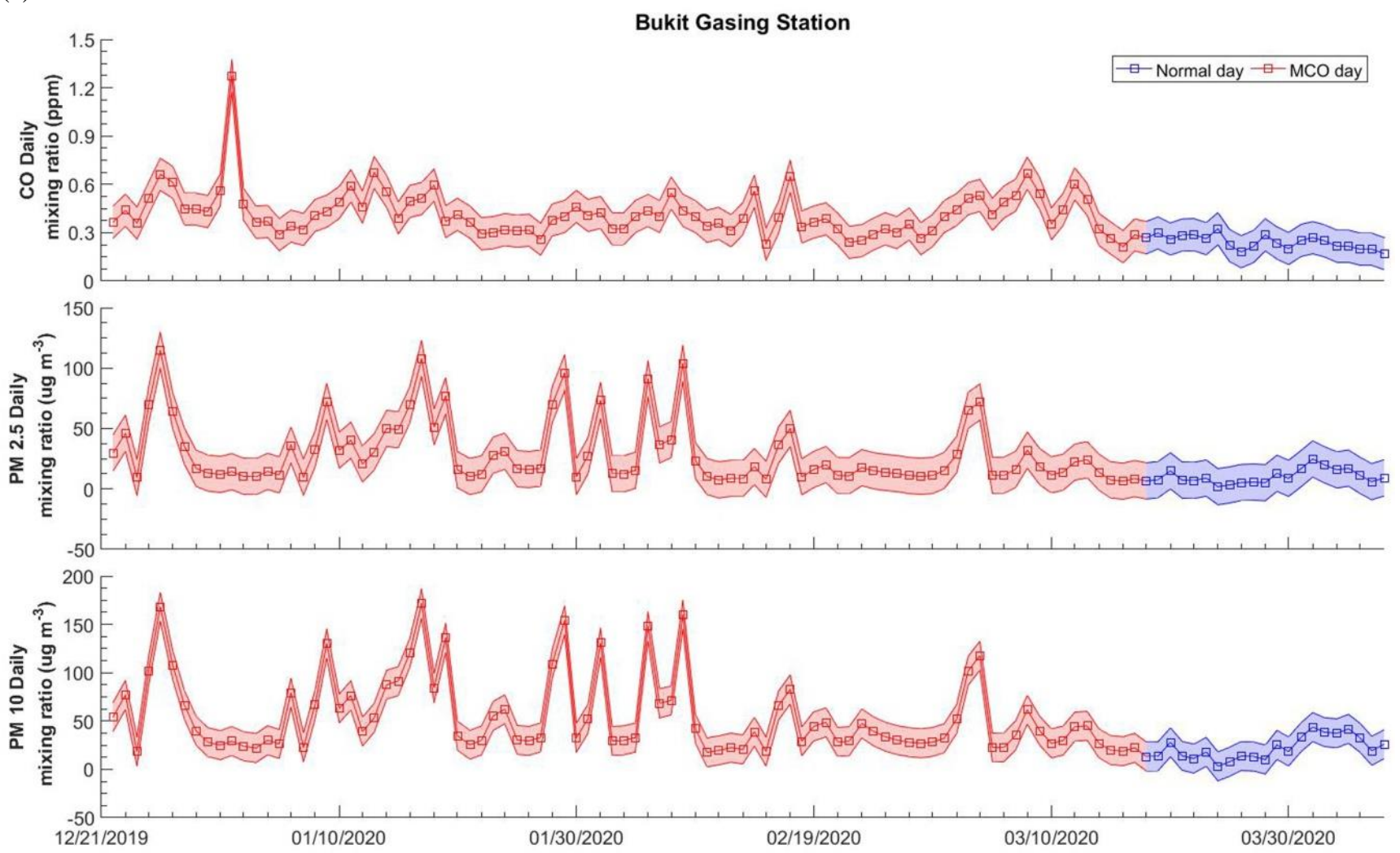

(b)
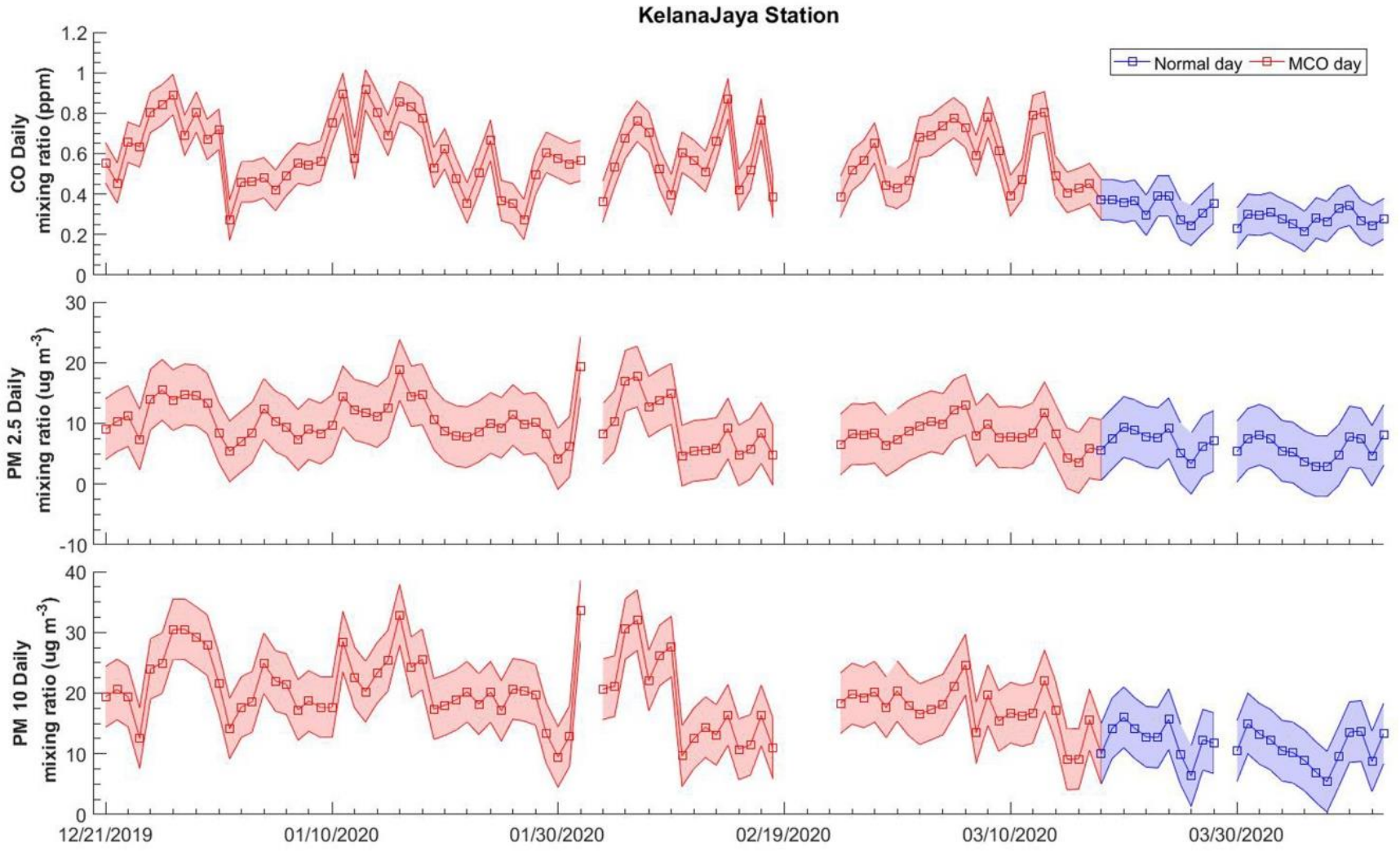

Fig. 2. Daily concentrations of $\mathrm{CO}, \mathrm{PM}_{2.5}$ and $\mathrm{PM}_{10}$ measured by AiRBOXSense over Petaling Jaya district from normal (red line) to MCO (blue line) periods with stations based at (a) Bukit Gasing, (b) Kelana Jaya, (c) Uptown PJ, (d) Kota Damansara, (e) PJ Town. 
(c)
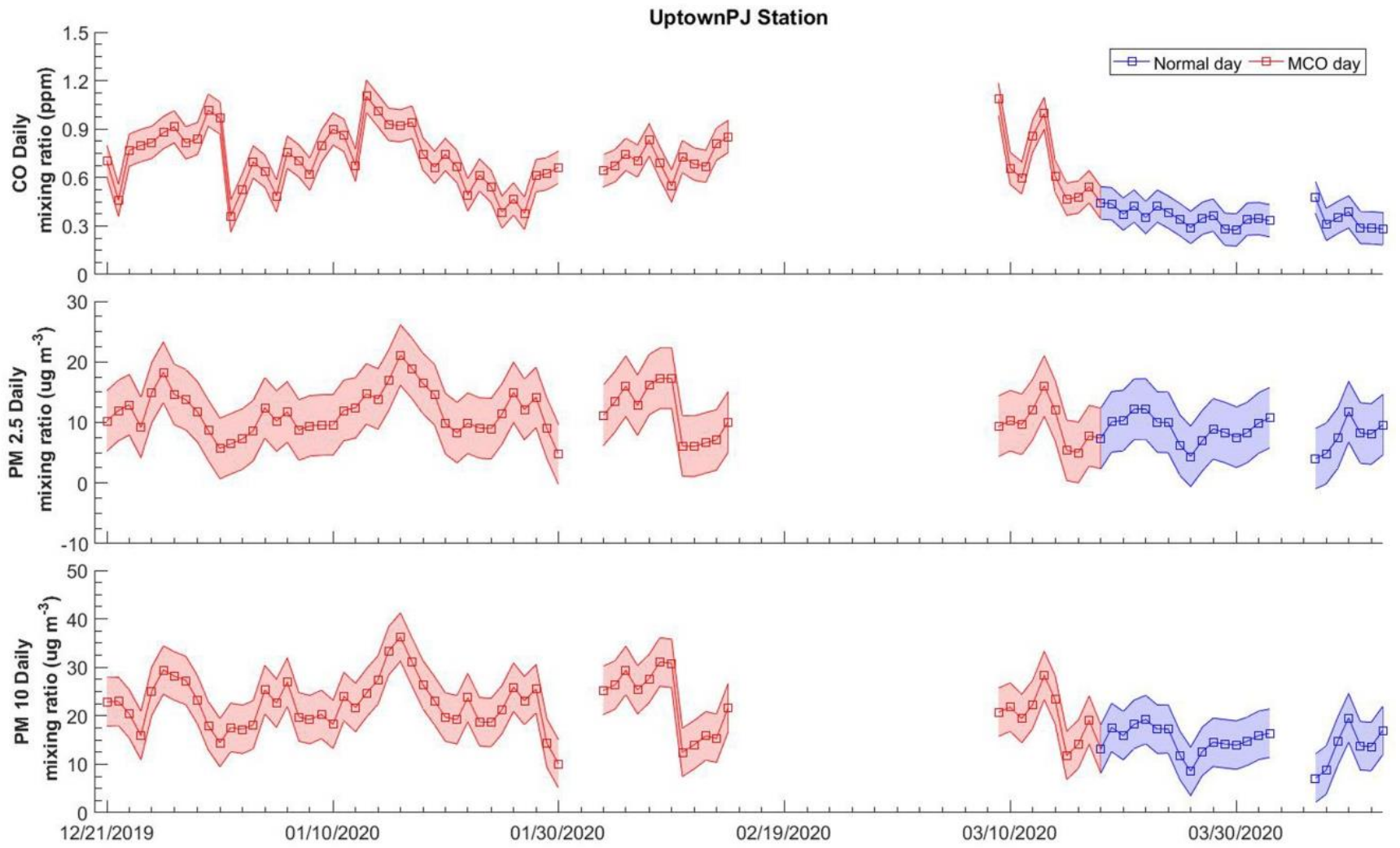

(d)
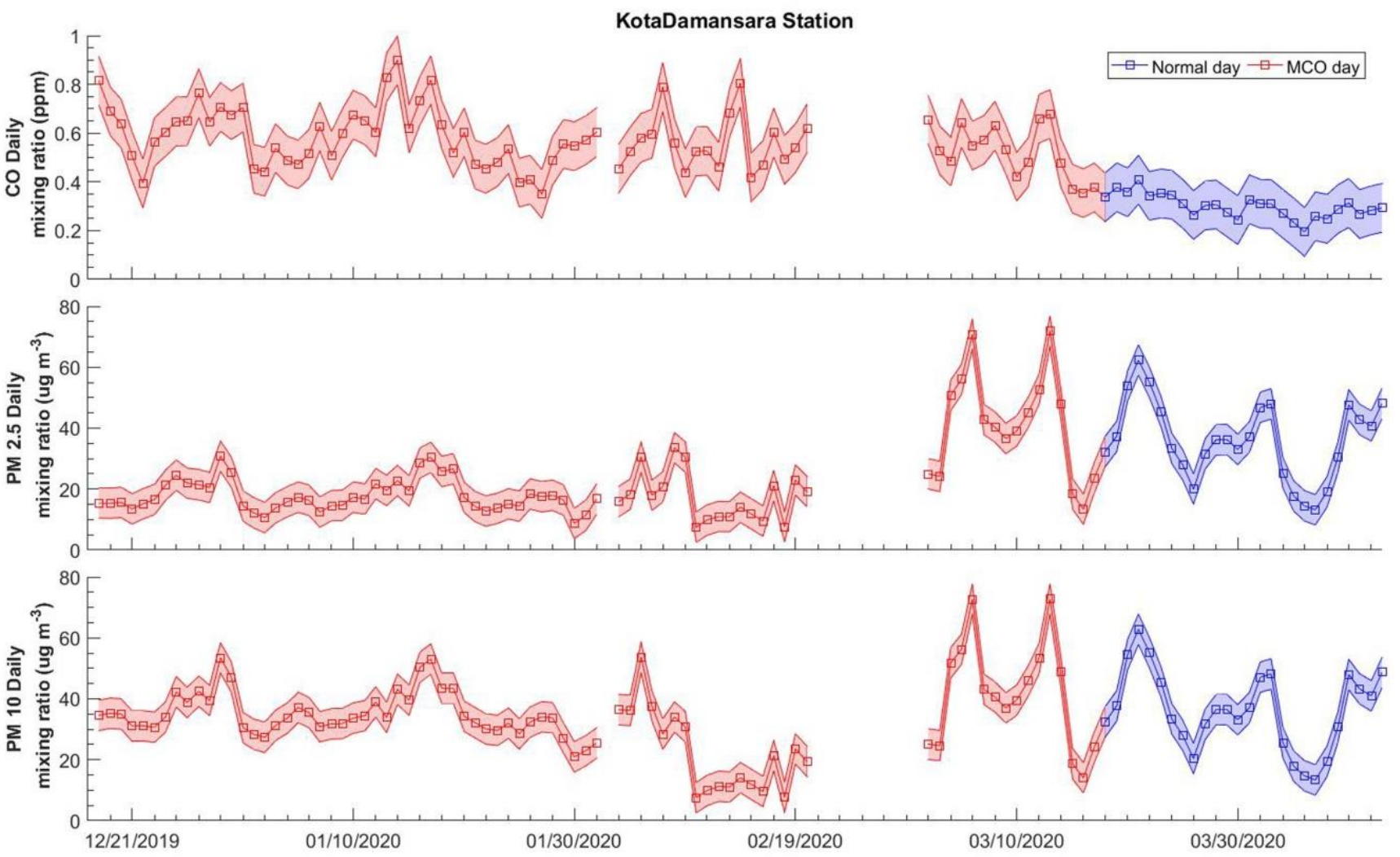

Fig. 2. (continued). 
(e)
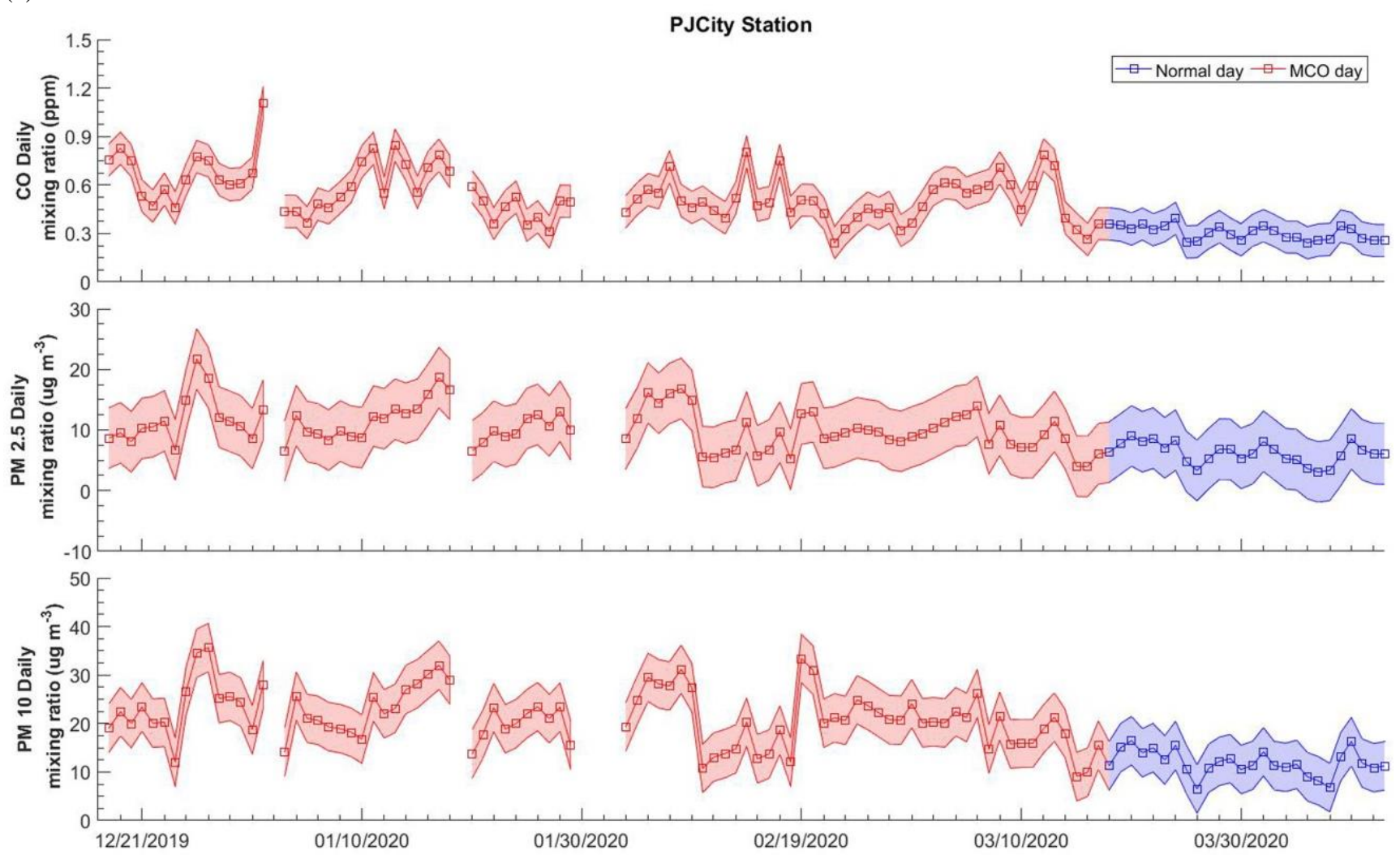

Fig. 2. (continued).

(a)

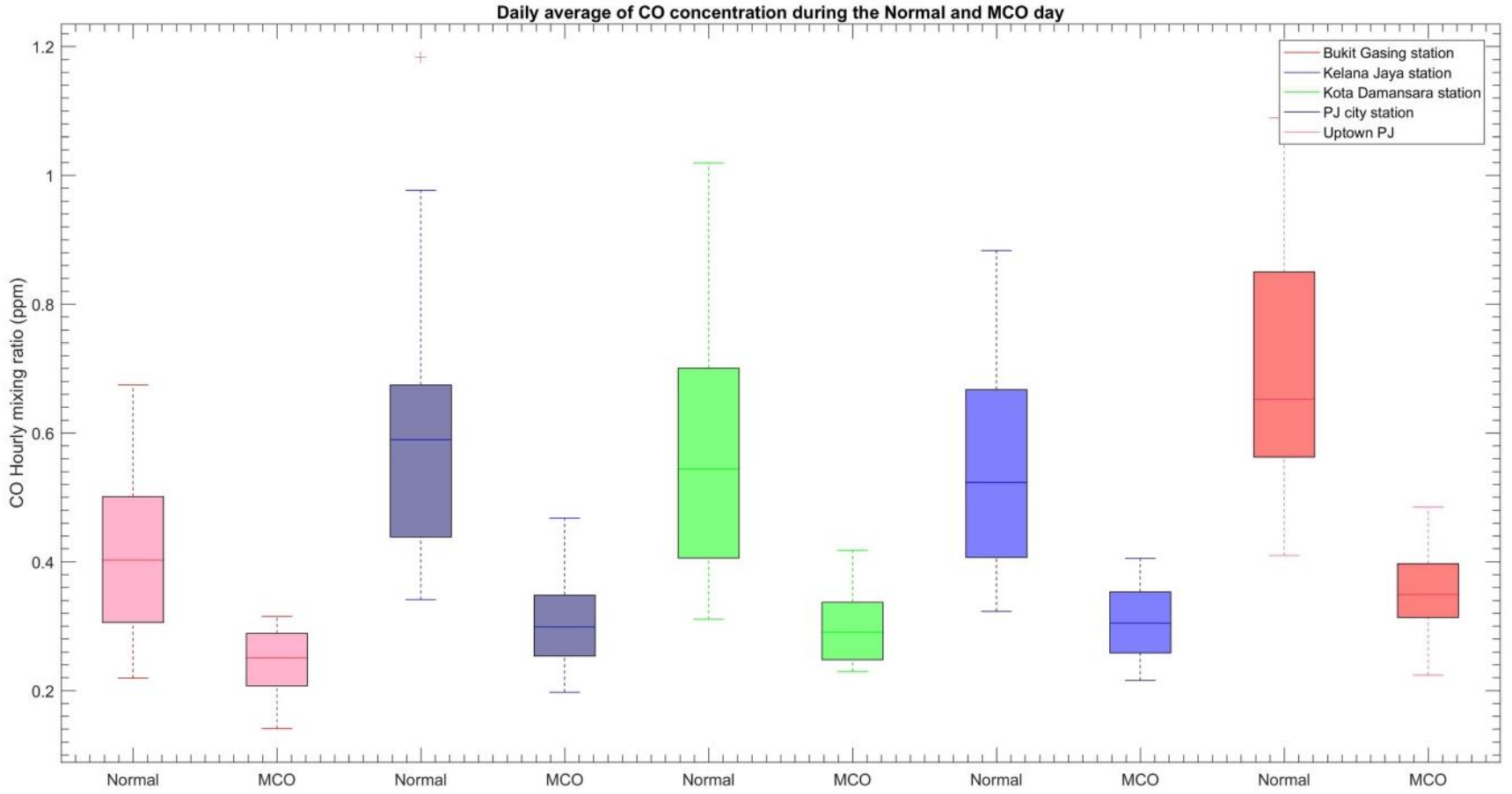

Fig. 3. Box and whisker plots of daily average (a) $\mathrm{CO}$, (b) $\mathrm{PM}_{2.5}$ and (c) $\mathrm{PM}_{10}$ concentrations during normal days and the MCO period. (Note: The top and bottom of each box represent the $75^{\text {th }}$ percentile and $25^{\text {th }}$ percentile respectively and the upper and lower whiskers represent the $90^{\text {th }}$ percentile and $10^{\text {th }}$ percentile, respectively. The horizontal bar in each box represents the data median.) 
(b)

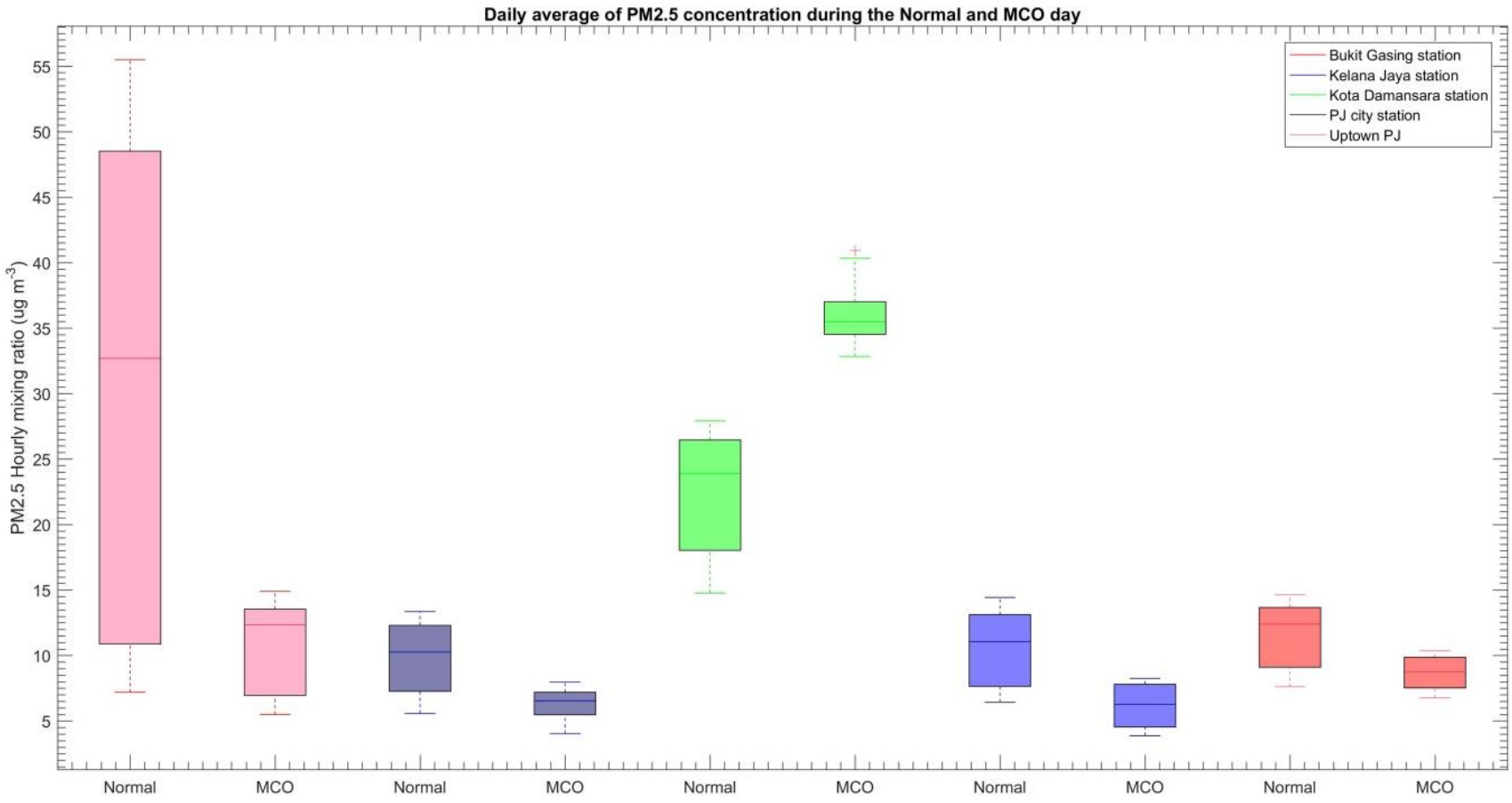

(c)

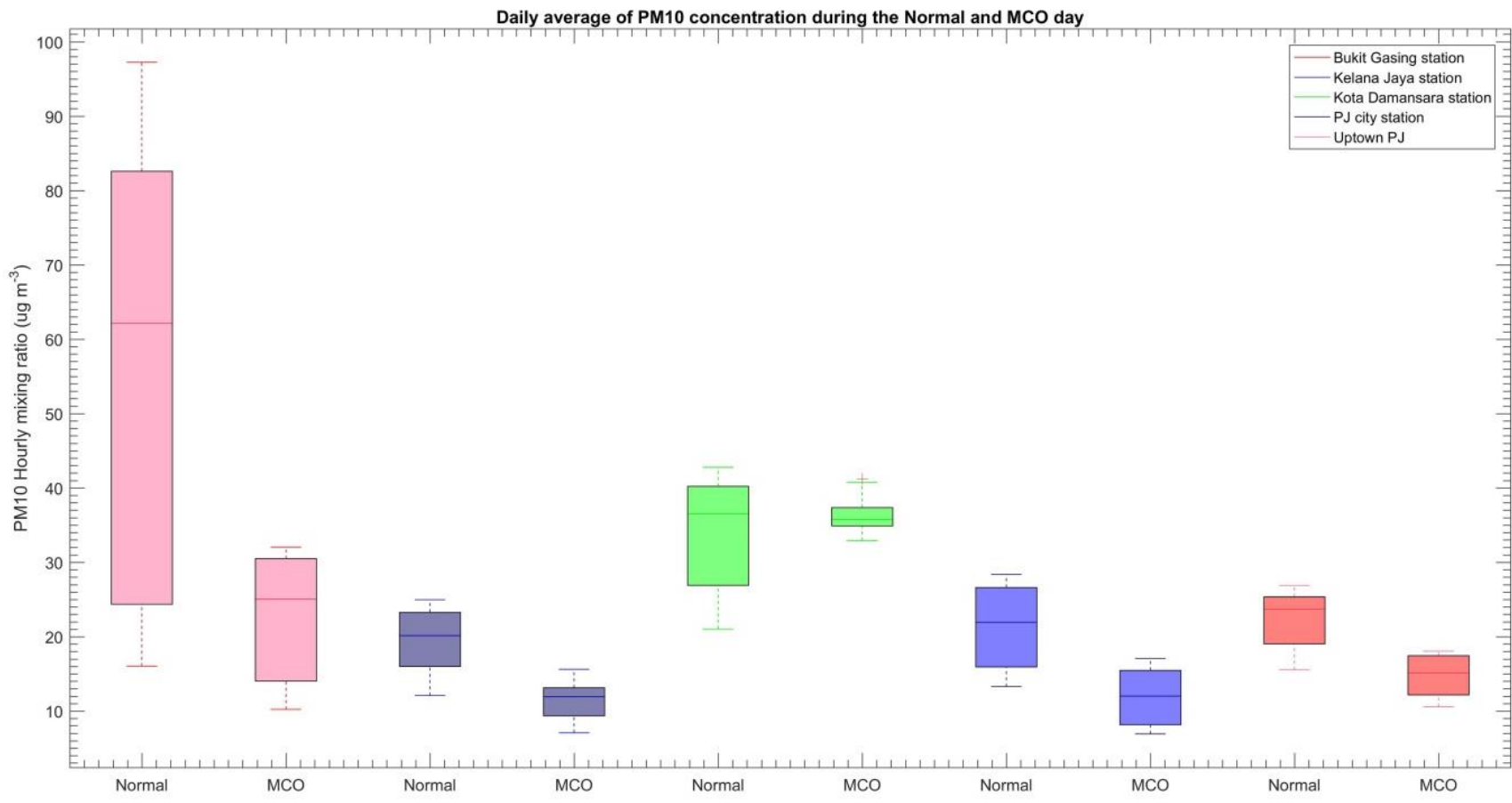

Fig. 3. (continued).

Nevertheless, the increase in both $\mathrm{PM}_{2.5}$ and $\mathrm{PM}_{10}$ can be explained due to the high concentration of construction activities in the area, mainly the construction of the DamansaraShah Alam Elevated Expressway (DASH Highway), in the surrounding area of KD that occurred during this short period of time. Due to the wind direction, particulate matter was transported to the sensor location. Another contributor was suspected to be small-scale burning activities by residents and construction workers who live and work nearby. This is to protect themselves from mosquito bites which can transmit dengue fever. These small fires are likely to have caused the increase in both the $\mathrm{PM}_{2.5}$ and $\mathrm{PM}_{10}$ levels (personal conversation with MBPJ enforcement officer). This suggests that despite the extensive implementation of emission control strategies, other emissions such as local burning or leakage from industries are difficult to control. 
Table 3. Overall reduction of the $\mathrm{CO}, \mathrm{PM}_{2.5}$ and $\mathrm{PM}_{10}$ recorded during $\mathrm{MCO}$ in Petaling Jaya. (Note: red bold indicates an increase in emissions.)

\begin{tabular}{|c|c|c|c|c|}
\hline Station & Sensor deployment & Type of area & Air pollutants & Average reduction $(\%)$ \\
\hline \multirow[t]{3}{*}{$\overline{\mathrm{BG}}$} & \multirow[t]{3}{*}{ Car park } & \multirow[t]{3}{*}{ Recreation area } & $\mathrm{CO}$ & 40.5 \\
\hline & & & $\mathrm{PM}_{2.5}$ & 58.9 \\
\hline & & & $\mathrm{PM}_{10}$ & 51.8 \\
\hline \multirow[t]{3}{*}{ KJ } & \multirow[t]{3}{*}{ Facing highway } & \multirow[t]{3}{*}{ Main highway } & $\mathrm{CO}$ & 45.2 \\
\hline & & & $\mathrm{PM}_{2.5}$ & 32.2 \\
\hline & & & $\mathrm{PM}_{10}$ & 34.9 \\
\hline \multirow[t]{3}{*}{ PJ City } & \multirow[t]{3}{*}{ Main road } & \multirow[t]{3}{*}{ Township and industrial } & $\mathrm{CO}$ & 44.1 \\
\hline & & & $\mathrm{PM}_{2.5}$ & 39.8 \\
\hline & & & $\mathrm{PM}_{10}$ & 42.0 \\
\hline \multirow[t]{3}{*}{ UP } & \multirow[t]{3}{*}{ Main road } & \multirow{3}{*}{$\begin{array}{l}\text { Residency, Mall, Shops } \\
\text { and restaurant area }\end{array}$} & $\mathrm{CO}$ & 47.5 \\
\hline & & & $\mathrm{PM}_{2.5}$ & 20.8 \\
\hline & & & $\mathrm{PM}_{10}$ & 28.8 \\
\hline \multirow[t]{3}{*}{ KD } & \multirow[t]{3}{*}{ Main road } & \multirow{3}{*}{$\begin{array}{l}\text { Residency and small } \\
\text { industries }\end{array}$} & $\mathrm{CO}$ & 44.7 \\
\hline & & & $\mathrm{PM}_{2.5}$ & +41.2 \\
\hline & & & $\mathrm{PM}_{10}$ & +14.2 \\
\hline
\end{tabular}

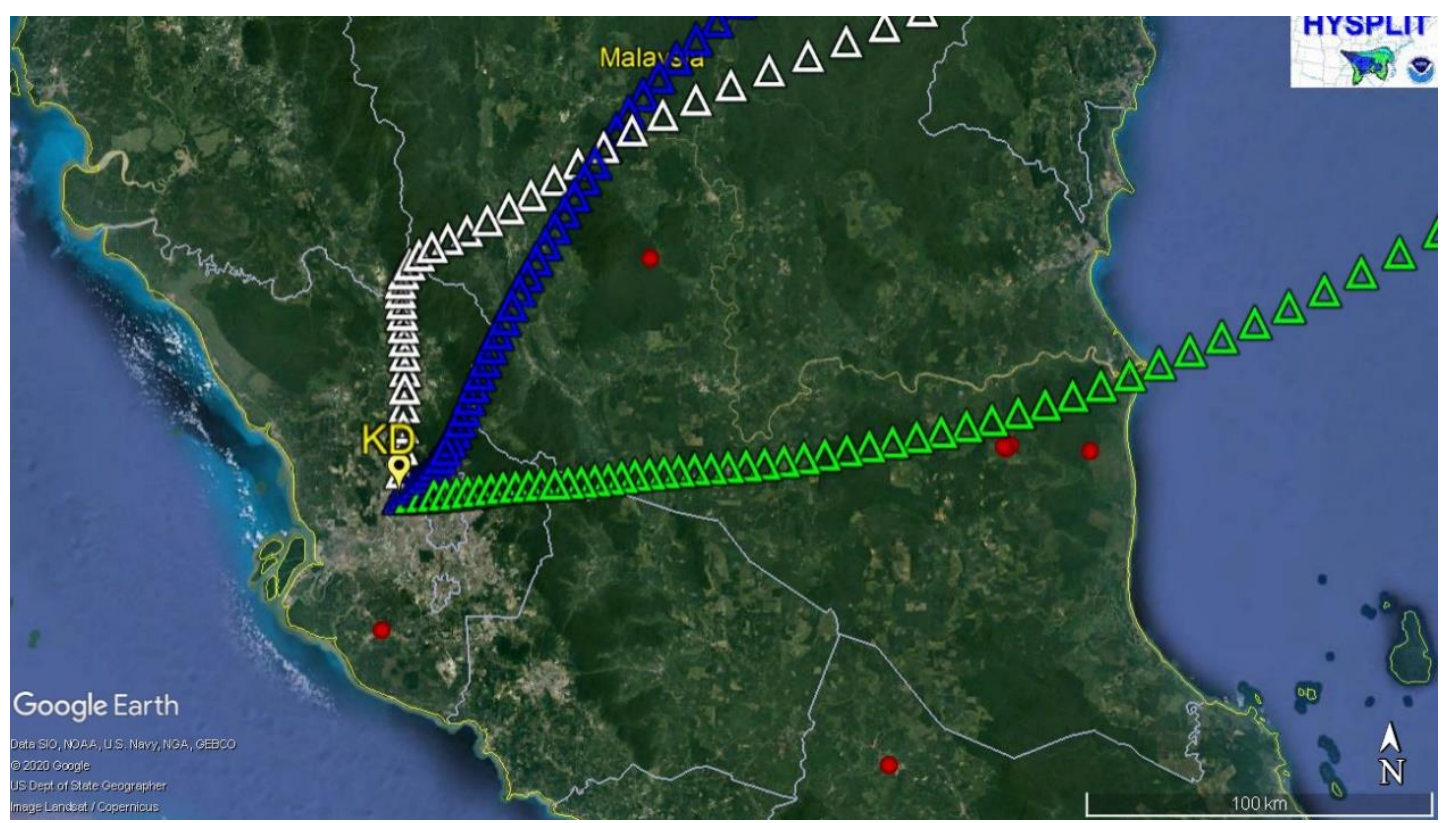

Fig. 4. The cluster means of backward trajectories of KD stations during high pollution period (18-22 Mar 2020) with green $(45 \%)$, blue $(40 \%)$ and white $(15 \%)$ triangles. The red dot marks the fire hotspot data from MODIS satellite during the same period (source map is from Google Earth).

\section{Other Observations}

The other interesting events detected during normal days are the week day and weekend effects observed by the sensors. The station that is most affected by the weekend effects is the one at BG. In order to determine the origins of $\mathrm{CO}, \mathrm{PM}_{2.5}$ and $\mathrm{PM}_{10}$, bivariate polar plots of the concentrations have been used to relate average values for the measurements with the wind speed and direction (November 2019February 2020) measured at PJ during the normal period using ERA 5 data (see Figs. 5-7). The highest $\mathrm{PM}_{2.5}$ and $\mathrm{PM}_{10}$ levels were observed at $\mathrm{BG}$ compared to other locations, especially during the weekend. The BG station represents the air quality at the car park of a big recreation park. The higher numbers of visitors to the BG recreation park during the weekend contributed to the related increment of vehicle emissions which was picked up by the downwind sensor (see Fig. 5(a)). Furthermore, high peaks were also observed over PJ Town and Kelana Jaya (KJ) (a highway area) but these were on weekdays during the rush hour (0700-0900) and were associated with strong north-easterly (NE) winds (see Figs. 5-7).

The northeast monsoon season begins in November and ends in March and April is the start of the intermonsoon period, but the wind direction is still mostly north-easterly and easterly. For effective emission controls, the weather conditions should also be taken into consideration (Wang et al., 2020). During this period of study (March-April), the Klang Valley region experienced the transitional period of 
(a)

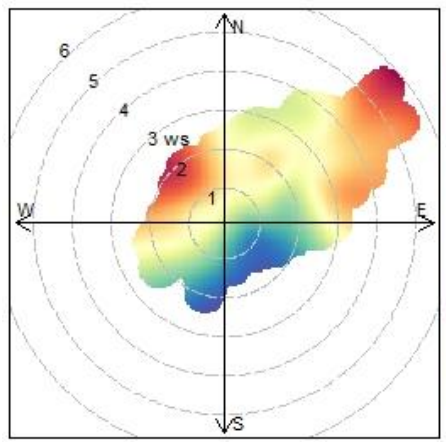

(b)

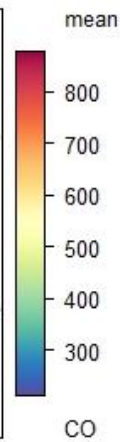

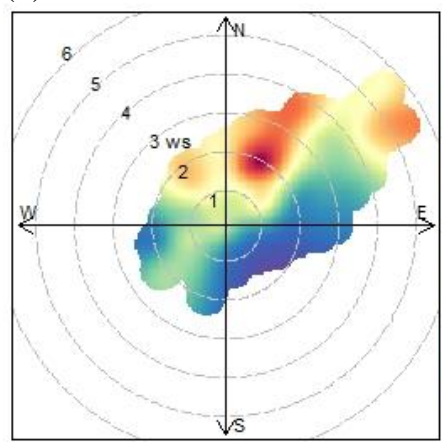

(c)

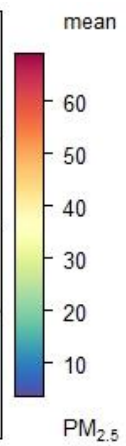

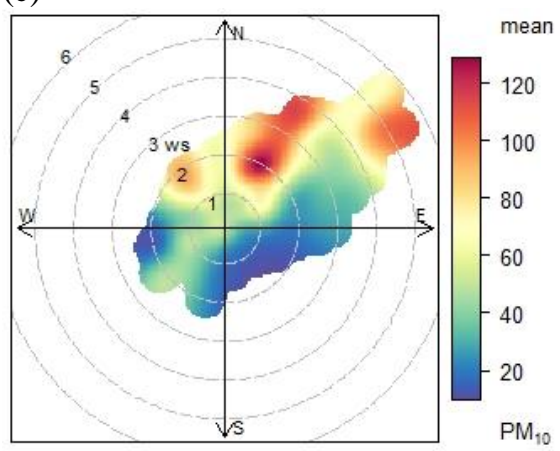

Fig. 5. Bipolar plots of (a) $\mathrm{CO}$, (b) $\mathrm{PM}_{2.5}$ and (c) $\mathrm{PM}_{10}$ using the wind data at $\mathrm{BG}$ during normal day using ERA5 data from the European Centre for Medium-Range Weather Forecasts (ECMWF).

(a)

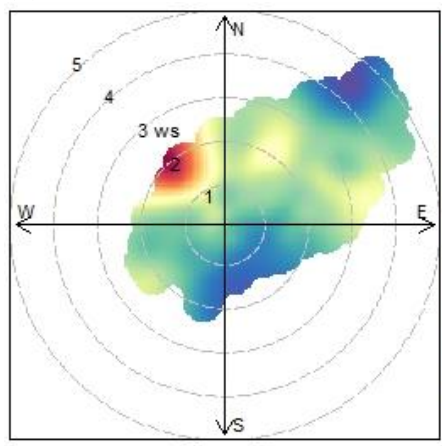

(b)

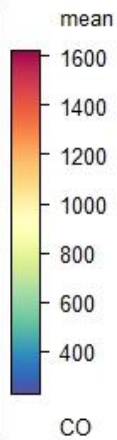

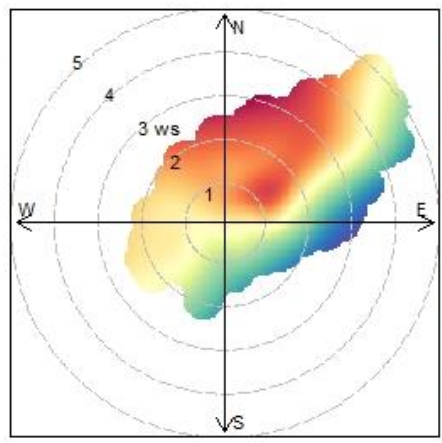

(c)
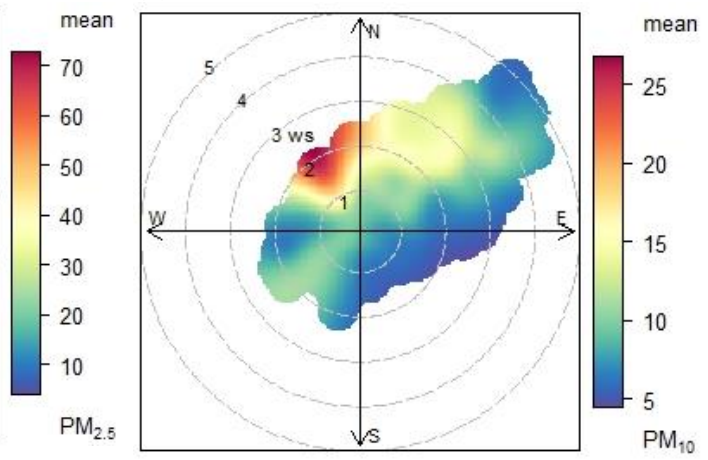

Fig. 6. Bipolar plots of (a) $\mathrm{CO}$, (b) $\mathrm{PM}_{2.5}$ and (c) $\mathrm{PM}_{10}$ over PJ using the wind data at $\mathrm{KJ}$ during normal day using ERA5 data from the European Centre for Medium-Range Weather Forecasts (ECMWF).

(a)

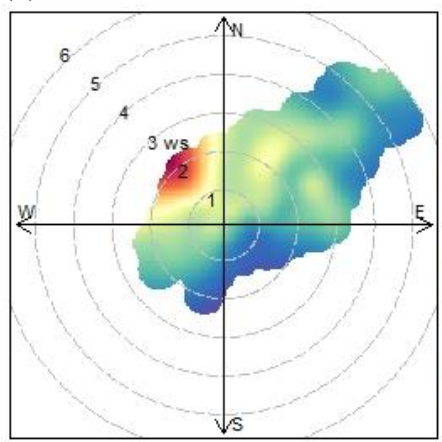

(b)

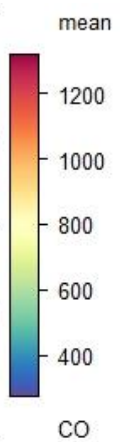

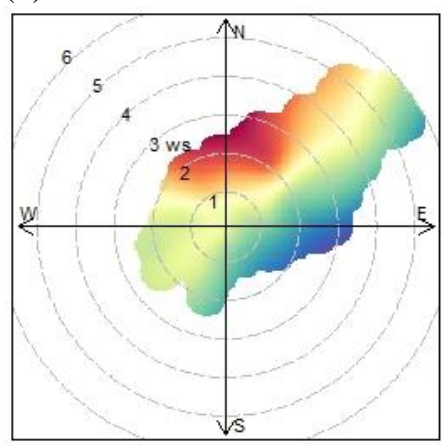

(c)

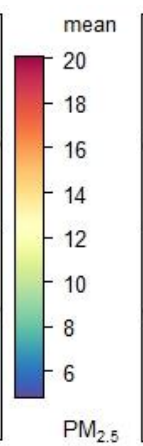

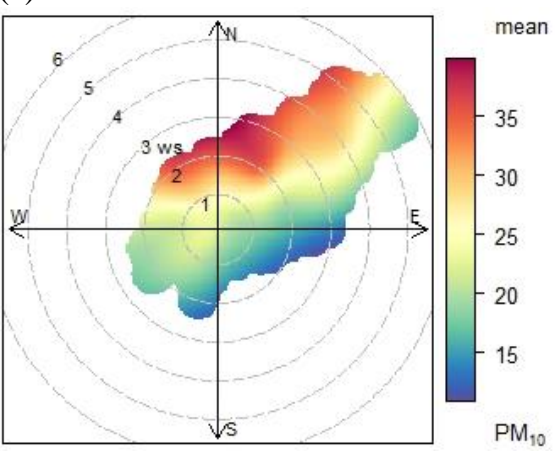

Fig. 7. Bipolar plots of (a) $\mathrm{CO}$, (b) $\mathrm{PM}_{10}$ and (c) $\mathrm{PM}_{2.5}$ at $\mathrm{PJ}$ City using the wind data at PJ BG during normal day using ERA5 data from the European Centre for Medium-Range Weather Forecasts (ECMWF).

intermonsoon weather with strong local convection and precipitation (Ooi et al., 2017). It also receives clean northeast air masses entering from the central backbone of Peninsular Malaysia as seen in Figs. 5-7.

\section{CONCLUSIONS AND PERSPECTIVES}

In this study, the concentrations of $\mathrm{CO}, \mathrm{PM}_{2.5}$ and $\mathrm{PM}_{10}$ were observed by AiRBOXSense sensors and CAQMS over the Klang Valley region. The historical data from CAQMS stations were used to identify the background level air quality close to the sensor locations. The sensors measured the air quality during normal days and the MCO period. Both monitoring techniques were used to explain the spatial variation in the reductions in concentrations of the measured pollutants over the urban Petaling Jaya district in Klang Valley. According to these results, average daily concentrations from historical data observed by CAQM were in the same range as daily average concentrations measured by the sensors during normal days for $\mathrm{CO}$ and $\mathrm{PM}_{2.5}$ and $\mathrm{PM}_{10}$. All 
the maximum levels for all pollutants were observed during peak rush hours during normal days due to traffic emissions. During MCO, however, the concentrations reduced by $\sim 40$ $50 \%$ for CO and $\sim 20-60 \%$ for particulate matter for most of the PJ sensor locations due to the reduction in vehicle numbers and industrial operations. Both $\mathrm{PM}_{2.5}$ and $\mathrm{PM}_{10}$ were increased in KD during the MCO period and this was suspected to be due to local burning activities and the highway construction nearby. North-east airflows cause pollutants to build up close to the sensor locations during both normal days and the MCO period. The meteorological effects on emission controls will be further discussed in the future using observation data with longer periods as well as numerical modelling tools.

\section{AUTHOR CONTRIBUTIONS}

Data analysis was done by MSMN, AAAM, MAAB, KMA, NMA and MFFMN. MSMN, MCGO, MTL, SHMA, HHAH and MZMN contributed to the discussion and interpretation of the results. MSMN, MCGO, MZMN, FA, NMH, AA and JA wrote the manuscript. MSMN, SHMA and KMA carried out the measurements. All the authors commented on the manuscript.

\section{COMPETING INTERESTS}

The authors declare that they have no conflict of interest.

\section{ACKNOWLEDGEMENTS}

We would like to thank Universiti Kebangsaan Malaysia (UKM) and Newton Ungku Omar Fund project number XX2017-002. Dr. Mohd Shahrul Mohd Nadzir would like to thank hanks to the Mayor of Petaling Jaya City Council (MBPJ) Dato Mohd Sayuthi bin Bakar for having great vision to make PJ as a smart city and to the rest of MBPJ staff. This study relies on archived historical air quality data from The Malaysian Department of the Environment (DOE) who providing all of the necessary investigative information and air quality data for the process of conducting our research. ERA5 data were generated using Copernicus Climate Change Service toolbox in this publication. We also like to thank Rose Norman (UK) for her assistance in proofreading this article. We also like to thank all scientists and engineers from the Pakar Scieno TW Sdn Bhd for their contributions to this research study. Finally, we would like to send our appreciation to all of our brave frontliners around the world during the times of crisis.

\section{REFERENCES}

Abdullah, S., Abu Mansor, A., Mohd Napi, N.N.L., Wan Mansor, W.N., Ahmed, A.N., Ismail, M. and Ahmad Ramly, Z.T. (2020). Air quality status during 2020 Malaysia Movement Control Order (MCO) due to 2019 novel coronavirus (2019-nCoV) pandemic. Sci. Total Environ. 729: 139022. https://doi.org/10.1016/j.scitotenv. 2020.139022
Alavi-Shoshtari, M., Williams, D.E., Salmond, J.A. and Kaipio, J.P. (2013). Detection of malfunctions in sensor networks. Environmetrics 24: 227-236. https://doi.org/10. 1002/env.2206

Alhasa, K.M., Mohd Nadzir, M.S., Olalekan, P., Latif, M.T., Yusup, Y., Iqbal Faruque, M.R., Ahamad, F., Abd. Hamid, H.H., Aiyub, K., Md Ali, S.H., Khan, M.F., Abu Samah, A., Yusuff, I., Othman, M., Tengku Hassim, T.M.F. and Ezani, N.E. (2018). Calibration model of a low-cost air quality sensor using an adaptive neuro-fuzzy inference system. Sensors 18: 4380. https://doi.org/10.33 90/s18124380

Austin, E., Novosselov, I., Seto, E., and Yost, M.G. (2015). Laboratory evaluation of the Shinyei PPD42NS low-cost particulate matter sensor. PLoS One 10: e0141928. https://doi.org/10.1371/journal.pone.0137789

Banan, N., Latif, M.T., Juneng, L. and Ahamad, F (2013) Characteristics of surface ozone concentrations at stations with different backgrounds in the Malaysian Peninsula. Aerosol Air Qual. Res. 13: 1090-1106. https://doi.org/10. 4209/aaqr.2012.09.0259

Cai, G., Cui, X., Zhu, X. and Zhou, J. (2020). A hint on the COVID-19 risk: Population disparities in gene expression of three receptors of SARS-CoV. Preprints 2020: 2020020408. https://doi.org/10.20944/preprints202002.0 408.v1

Conticini, E., Frediani, B. and Caro, D. (2020). Can atmospheric pollution be considered a co-factor in extremely high level of SARS-CoV-2 lethality in Northern Italy? Environ. Pollut. 261: 114465. https://doi.org/10.1016/j.e nvpol.2020.114465

Copernicus Climate Change Service (C3S) (2017). ERA5: Fifth generation of ECMWF atmospheric reanalyses of the global climate. Copernicus Climate Change Service Climate Data Store (CDS), https://cds.climate.copernicus.eu/

Draxler, R. and Rolph, G. (2003.) HYSPLIT (HYbrid Single-particle Lagrangian Integrated Trajectory) Model Access via NOAA ARL READY Website. NOAA Air Resources Laboratory, Silver Spring, MD. http://www.arl. noaa.gov/ready/hysplit4.html

EcoWatch (2020, April 02). India's air pollution plummets in COVID-19 Lockdown. https://www.ecowatch.com/indiaair-pollution-coronavirus-2645617908.html.

Hadei, M., Hopke, P.K., Jonidi, A. and Shahsavani, A. (2020). A letter about the airborne transmission of SARSCoV-2 based on the current evidence. Aerosol Air Qual. Res. 20: 991-914. https://doi.org/10.4209/aaqr.2020.04.0158

He, G., Pan, Y. and Tanaka, T. (2020). COVID-19, city lockdowns, and air pollution: Evidence from China. medRxiv. 2020.03.29.20046649 https://doi.org/10.1101/2 020.03.29.20046649

Hsiao, T.C., Chuang, H.C., Griffith, S.M., Chen, S.J. and Young, L.H. (2020). COVID-19: An aerosol's point of view from expiration to transmission to viral-mechanism. Aerosol Air Qual. Res. 20: 905-910. https://doi.org/10.42 09/aaqr.2020.04.0154

Justice, C., Townshend, J., Vermote, E., Masuoka, E., Wolfe, R., Saleous, N., Roy, D. and Morisette, J. (2002). An overview of MODIS land data processing and product 
status. Remote Sens. Environ. 83: 3-15. https://doi.org/10. 1016/S0034-4257(02)00084-6

Latif, M.T., Huey, L.S. and Juneng, L. (2012). Variations of surface ozone concentration across the Klang Valley, Malaysia. Atmos. Environ. 61: 434-445. https://doi.org/ 10.1016/j.atmosenv.2012.07.062

Nadzir, M.S.M., Ashfold, M.J., Khan, M.F., Robinson, A.D., Bolas, C., Latif, M.T., Wallis, B.M., Mead, M.I., Hamid, H.H.A., Harris, N.R.P., Ramly, Z.T.A., Lai, G.T., Liew, J.N., Ahamad, F., Uning, R., Samah, A.A., Maulud, K.N., Suparta, W., Zainudin, S.K., ... Sasso, N.D. (2018). Spatial-temporal variations in surface ozone over Ushuaia and the Antarctic region: Observations from in situ measurements, satellite data, and global models. Environ. Sci. Pollut. Res. 25: 2194. https://doi.org/10.1007/s11356017-0521-1

Ooi, M.C.G., Chan, A., Subramaniam, K., Morris, K.I. and Oozeer, M.Y. (2017). Interaction of urban heating and local winds during the calm inter-monsoon seasons in the tropics. J. Geophys. Res. 122: 11499-11523. https://doi.org /10.1002/2017JD026690.

Rolph, G. (2003). Real-time Environmental Applications and Display System (READY) Website. NOAA Air Resources Laboratory, Silver Spring, MD. http://www.arl.noaa.gov/ready/hysplit4.html

Sharma, S., Zhang, M., Ansika, Gao, J., Zhang, H. and Kota, S.H. (2020) Effect of restricted emissions during COVID19 on air quality in India. Sci. Total Environ. 728: 138878. https://doi.org/10.1016/j.scitotenv.2020.139022.

The Conversation (2020, April 15). Coronavirus: lockdown's effect on air pollution provides rare glimpse of lowcarbon future. https://theconversation.com/coronaviruslockdowns-effect-on-air-pollution-provides-rare-glimpse- of-low-carbon-future-134685

Wang, P., Chen, K., Zhu, S., Wang, P. and Zhang, H. (2020) Severe air pollution events not avoided by reduced anthropogenic activities during COVID-19 outbreak. Resour. Conserv. Recycl. 158: 104814. https://doi.org/10. 1016/j.resconrec.2020.104814, 2020.

World Health Organization (WHO) (2016). Mortality and burden of disease from ambient air pollution. https://www.who.int/gho/phe/outdoor_air_pollution/burd en/en/

World Health Organization (WHO) (2018, May 2). Ambient (outdoor) air quality and health. http://www.who.int/med iacentre/factsheets/fs313/en/

World Health Organization (WHO) (2020, March 11). WHO Director-General's opening remarks at the media briefing on COVID-19 - 11 March 2020. https://www.who.int/dg/ speeches/detail/who-director-general-s-opening-remarksat-the-media-briefing-on-covid-19---11-march-2020

Wu, X., Nethery, R.C., Sabath, B.M., Braun, D. and Dominici, F. (2020) Exposure to air pollution and COVID-19 mortality in the United States. medRxiv 2020.04.05.20054502 https://doi.org/10.1101/2020.04.05.20054502

Xu, K., Cui, K., Young, L.H., Hsieh, Y.K., Wang, Y.F., Zhang, J. and Wan, S. (2020). Impact of the COVID-19 event on air quality in central China. Aerosol Air Qual. Res. 20: 915-929. https://doi.org/10.4209/aaqr.2020.04.0 150

Received for review, April 26, 2020

Revised, May 13, 2020

Accepted, May 15, 2020 